\title{
PENGARUH PEMBERIAN MINUMAN BEROKSIGEN TERHADAP NILAI $\mathrm{VO}_{2} \mathrm{MAX}$
}

\author{
Oleh \\ Fajar Apollo Sinaga', Natanael Putragon Manalu' ${ }^{1}$ \\ ${ }^{I}$ Fakultas Ilmu Keolahragaan, Universitas Negeri Medan \\ Email: natanaelmanalu@gmail.com
}

\begin{abstract}
Abstrak
Kemampuan aerobic ( $\left.\mathrm{VO}_{2} m a x\right)$ adalah kemampuan olah daya aerobic terbesar yang dimiliki seseorang. Mereka yang mempunyai $\mathrm{VO}_{2} \mathrm{max}$ yang tinggi dapat melakukan lebih banyak pekerjaan sebelum menjadi lelah, dibandingkan dengan mereka yang mempunyai $\mathrm{VO}_{2} \max$ yang lebih rendah. Air minum penambah oksigen termasuk ke dalam jenis air minum dalam kemasan yang didalamnya ditambahkan oksigen terlarut sehingga mengandung jumlah oksigen yang jumlahnya lebih banyak dibandingkan dengan air minum biasa. Tujuan dari penelitian ini adalah untuk mengetahui pengaruh pemberian minuman beroksigen terhadap nilai $\mathrm{VO}_{2} \max$. Penelitian ini dilaksanakan pada tanggal 16 dan 20 Mei di halaman Stadion Universitas Negeri Medan JI. Willem Iskandar, Psr V Sumatera Utara. Sampel dalam penelitian ini adalah Mahasiswa Angkatan 2013 yang berjenis kelamin laki-laki Jurusan Ilmu Keolahragaan FIK-UNIMED yaitu sebanyak 10 orang. Metodologi penelitian yang digunakan adalah Randomized Pretest-Postest Group Design. Teknik analisis data yang digunakan adalah uji paramaterik yaitu uji $t$ berpasangan dan uji t tidak berpasangan dengan menggunakan program SPSS. Hasil penelitian diperoleh nilai rata-rata $\mathrm{VO}_{2}$ max pada pre tes kelompok eksperimen dengan rata-rata sebesar 35,7 dan hasil post test diperoleh hasil dengan rata-rata sebesar 35,9 atau terjadi peningkatan sebesar 0.2. Sedangkan pada kelompok kontrol pre tes diperoleh nilai $\mathrm{VO}_{2} \mathrm{max}$ dengan rata-rata sebesar 34,9 dan hasil pos tes diperoleh rata-rata sebesar 35,1 atau terjadi peningkatan sebesar 0,2 . Hasil uji-t tidak berpasangan diperoleh hasil p: $0,4549(>0,05)$ yang berarti tidak ada pengaruh yang signifikan. Maka dapat diambil kesimpulan bahwa tidak terdapat pengaruh pemberian minuman beroksigen terhadap nilai $V_{2} \max$ Mahasiswa IKOR stambuk 2013 FIKUNIMED.
\end{abstract}

Kata Kunci: Minuman Beroksigen, $\mathrm{VO}_{2} \max$, Bleep Test

\section{A. PENDAHULUAN}

Air merupakan senyawa kimia yang sangat penting bagi kehidupan manusia dan makhluk hidup lainnya. Fungsi komponen ini tidak akan dapat digantikan oleh senyawa lainnya. Satu molekul air tersusun atas dua atom hidrogen yang terikat secara kovalen pada satu atom oksigen dengan bentuk V. Molekul air yang satu dengan molekul air lainnya bergabung dengan satu ikatan hidrogen, yaitu antara atom $\mathrm{H}$ molekul air satu dengan atom O dari molekul air yang lain (Parker, 2003). Menurut Lehninger (1982), 
air dan produk ionisasinya (ion $\mathrm{H}^{+}$dan $\mathrm{OH}^{-}$) sangat mempengaruhi sifat berbagai komponen penting sel, seperti enzim, asam nukleat, protein, dan lipid.

Air diketahui memiliki fungsi untuk proses transportasi mineral, vitamin, protein dan zat gizi lainnya keseluruh tubuh yang menyebabkan tubuh seorang individu menjadi lebih sehat. Air minum saat ini tidak hanya terbatas pada satu jenis saja. Seiring perkembangan zaman maka minuman memiliki banyak variasi yang dapat menjadi pilihan bagi masyarakat dalam mengkonsumsi minuman untuk menghilangkan rasa haus. Salah satu jenis minuman yang ada saat ini adalah minuman beroksigen.

Oksigen merupakan elemen paling vital di dunia karena tidak akan ada kehidupan tanpa keberadaan oksigen. Keberadaan elemen tersebut memproduksi setidaknya 90\% dari energi hidup yang ada. Menurut Thomas (2005), oksigen ditemukan pertama kali pada awal abad ke-18, tepatnya pada tahun 1773 oleh ilmuwan kimia berkebangsaan Swedia Karl Scheele dan Joseph Priestley yang berkebangsaan Inggris. Menurut Oxtoby et. al. (2007) molekul oksigen adalah/salah satu dari komponen utama penyusun udara. Kandungan oksigen di udara atau atmosfer sekitar $21 \%$ yang berbentuk molekul diatomik (O2). Sedangkan jika di atas lapisan permukaan atmosfer oksigen dapat ditemukan dalam bentuk molekul monoatomik (O) dan triatomik $(\mathrm{O} 3)$.

Oksigen yang terdapat di dalam minuman beroksigen dimasukkan ke dalam air lewat suatu proses dengan menggunakan tekanan. Seperti halnya ketika membuat minuman berkarbonasi ( minuman ringan ) yaitu dengan memompakan $\mathrm{CO}_{2}$ ke dalam air. Oksigen yang diserap melalui membran usus halus dan usus besar dapat meningkatkan imunitas dan memperbaiki sistem sirkulasi dalam tubuh seseorang yang meminumnya. Fungsi lain oksigen juga akan melekat pada butir-butir darah merah yang kemudian masuk ke dalam sel-sel tubuh manusia. Oksigen juga diperlukan oleh sel untuk mengubah glukosa menjadi energi dalam proses metabolisme yang dibutuhkan untuk melakukan berbagai aktivitas, seperti aktivitas fisik, penyerapan makanan, membangun kekebalan tubuh, pemulihan kondisi tubuh, juga penghancuran beberapa racun sisa metabolisme.

Minuman beroksigen atau yang sering disebut dengan minuman "super oxygenated" diketahui memiliki kandungan oksigen yang lebih besar dibandingkan dengan minuman biasanya yaitu sekitar 7-10 kali lebih banyak. Air minum beroksigen 
dalam dunia olahraga diyakini dapat meningkatkan kapasitas oksigen yang dibawa oleh darah. Peningkatan stamina fisik dan peningkatan kapasitas oksigen terjadi apabila ketahanan kardio-respirasi pada tubuh berlangsung dengan baik.

Daya tahan kardio-respirasi (VO2Max) adalah kesanggupan sistem jantung, paru dan pembuluh darah untuk berfungsi secara optimal pada keadaan istirahat dan kerja dalam mengambil oksigen dan menyalurkannya ke jaringan yang aktif sehingga dapat digunakan pada proses metabolisme tubuh (DepKes, 1999). Kemampuan aerobic (VO2max) adalah kemampuan olah daya aerobic terbesar yang dimiliki seseorang. Hal ini ditentukan oleh jumlah zat asam $\left(\mathrm{O}_{2}\right)$ yang paling banyak dapat dipasok oleh jantung, pernapasan, dan hemo-hidro-limpatik atau transport $\mathrm{O}_{2}, \mathrm{CO}_{2}$ dan nutrisi pada setiap menit (Karpovich, dalam Santoso, 1992). Menurut Devies (dalam Joesoef, 1988)yang dimaksud dengan $\mathrm{VO}_{2}$ max adalah derajat metabolisme aerob maksimum dalam aktivitas fisik dinamis yang dapat dicapai seseorang. Sedangkan menurut Thoden (dalam Sukarman, 1992), yang dimaksud dengan $V O_{2} m a x$ adalah: "Daya tangkap aerobic maksimal menggambarkan jumlah oksigen maksimum yang dikonsumsi per satuan waktu oleh seseorang selama latihan atau tes, dengan latihan yang makin lama makin berat sampai kelelahan, ukurannya disebut $\mathrm{VO}_{2} \max$. Sesuai pernyataan tersebut dapat dikatakan bahwa air minum beroksigen dapat meningkatkan ketahanan kardio-respirasi, walaupun hal ini masih sangat krontroversial.

Dewasa ini, air minum beroksigen semakin banyak kita temui di pasar bebas. Para produsen menjanjikan bahwa air minum tersebut memiliki beragam manfaat yang menyehatkan tubuh karena mengandung 7-10 kali jumlah oksigen yang lebih banyak dibadingkan dengan air minum biasa. Sehingga diharapkan tubuh yang mengalami defisit oksigen setelah berolahraga akan digantikan oleh oksigen yang telah mengalami absorbsi di dalam usus. Para konsumen percaya bahwa dengan mengkonsumsi minuman beroksigen ini, akan meningkatkan kapasitas oksigen di dalam darah dan memperkuat daya tahan tubuh, meskipun hal ini belum terbukti.

Penelitian oleh Marieb dan Hoehn melaporkan bahwa penggunaan oksigen dalam latihan fisik tidak akan mempengaruhi keadaan tubuh yang sedang kekurangan oksigen, seperti contohnya para atlet yang menggunakan oksigen murni untuk mempercepat proses pemulihan akibat kekurangan, karena menurutnya setelah beraktivitas fisik, yang kekurangan oksigen adalah jaringan-jaringan otot, bukan paru, 
sehingga oksigen yang ia hirup dianggap tidak bermanfaat karena tidak mencapai otot. Berbeda dengan apa yang disampaikan oleh White yang melaporkan bahwa penggunaan oksigen saat sedang latihan dan setelah latihan sangat menmbantu kondisi tubuh yang sedang kekurangan oksigen.

Hal tersebut di atas belum jelas terbukti kebenarannya, dikarenakan oksigen yang mengalami absorbsi melalui sistem gastrointestinal hanya memberikan kandungan jumlah oksigen yang sedikit daripada jumlah oksigen yang didapat dari sistem pernafasan. Penelitian tentang pengaruh minuman beroksigen terhadap nilai $\mathrm{VO}_{2} \max$ perlu dilakukan untuk meneliti lebih lanjut mengenai manfaat yang diberikan oleh air minum beroksigen yang disebutkan dapat mengembalikan stamina fisik dan dapat meningkatkan kapasitas oksigen yang dibawa oleh darah.

\section{B. METODE PENELITIAN}

Penelitian ini dilaksanakan di Stadion Universitas Negeri Medan J1. Willem Iskandar, Psr V Sumatera Utara, pada tanggal 16/dan 20 Mei 2017. Subyek penelitian berjumlah 10 orang mahasiswa Jurusan Ilmu Keolahragaan Fakultas Ilmu Keolahragaan Universitas Negeri Medan.

Metode yang digunakan dalam penelitian ini adalah metode eksperimental dengan menggunakan rancangan "Randomized Pretest-Postest Group Design. Prosedurnya adalah sampel akan dibagi menjadi 2 kelompok, yaitu kelompok eksperimen (yang diberikan minuman beroksigen sebanyak 400cc) dan kelompok kontrol (diberikan minuman air mineral biasa). Untuk mengukur/ menghitung nilai $\mathrm{VO}_{2} \max$ sebelum dan sesudah pemberian minuman beroksigen menggunakan bleep test.

Data yang telah dikumpulkan dari pre-test dan post-test dianalisis dengan menggunkan statistik:

1. Uji homogenitas

2. Uji normalitas

3. Uji t

\section{HASIL PENELITIAN DAN PEMBAHASAN}

\section{HASIL PENELITIAN}

Berdasarkan hasil penelitian yang dilakukan, maka dilihat rata-rata kemampuan VO2max sebelum dan sesudah diberikan minuman beroksigen dan minuman air mineral dengan hasil sebagai berikut. 


\section{Tabel 1.}

Rangkuman Hasil Analisis Data Pre-Test Dan Post-Test Kelompok Eksperimen

\begin{tabular}{clcc}
\hline NO & NAMA SAMPEL & PRE- TEST & POST-TEST \\
\hline 1 & Doni Alpian Capah & 35,7 & 35,7 \\
\hline 2 & Leonardo Silitonga & 34,7 & 34,7 \\
\hline 3 & Rikardo T Nababan & 36 & 36,4 \\
\hline 4 & Simon Eduardo Sihite & 35,7 & 36 \\
\hline 5 & Supriadi Situmeang & 36,4 & 36,8
\end{tabular}

Tabel 2.

Rangkuman Hasil Analisis Data Pre-Test Dan Post-Test Kelompok Kontrol

\begin{tabular}{llcc}
\hline NO & NAMA SAMPEL & PRE- TEST & POST-TEST \\
\hline 1 & Dedy Bahari & 35,4 & 35,7 \\
\hline 2 & Joko Dermawan & 34,7 & 34,7 \\
\hline 3 & Mariono Sibagariang & 35,4 & 35,4 \\
\hline 4 & Urat Purnama Sipahutar & 34,3 & 34,7 \\
\hline 5 & Thariq Hafiz & 35 & 35,4 \\
\hline & & \\
\hline
\end{tabular}

Data Deskriptif Kemampuan $\mathrm{VO}_{2} \max$ Berdasarkan Sebelum Dan Sesudah Pemberian Minuman Beroksigen Dan Minuman Air Mineral Pada Bleep Test.

\begin{tabular}{clcc|cc}
\hline \multirow{2}{*}{ No } & \multirow{2}{*}{ Kelompok } & \multicolumn{2}{c|}{ Pre tes } & \multicolumn{2}{c}{ Post tes } \\
\cline { 3 - 6 } & & Rata-rata & $\begin{array}{c}\text { Standar } \\
\text { Deviasi }\end{array}$ & Rata-rata & $\begin{array}{c}\text { Standar } \\
\text { Deviasi }\end{array}$ \\
\hline 1 & Minuman Beroksigen & 35,7 & 0,6284 & 35,9 & 0,7981 \\
\hline 2 & Air mineral & 34,9 & 0,4722 & 35,1 & 0,4549 \\
\hline
\end{tabular}

a. Kelompok Eksperimen

Hasil pemeriksaan kemampuan $\mathrm{VO}_{2} \max$ pada saat pre test menunjukkan nilai rata-rata kemampuan $\mathrm{VO}_{2} \max$ sebesar 35,7 dan standar deviasi sebesar 0,6284. Setelah pemberian minuman beroksigen pada sampel kemampuan $\mathrm{VO}_{2} \max$ pada saat post test dengan rata-rata sebesar 35,9 dan standar deviasi sebesar 0,7981.

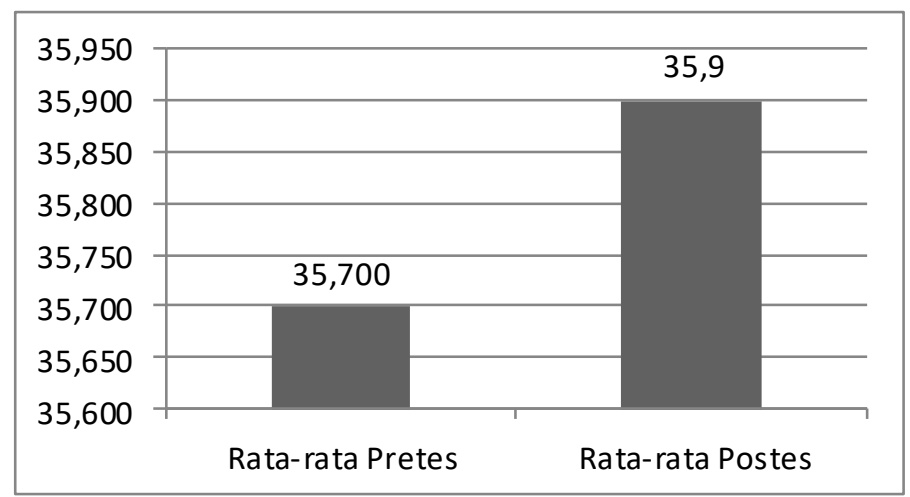

Gambar 1. Histogram Rata-Rata Kemampuan $\mathrm{VO}_{2} \max$ Kelompok Eksperimen 


\section{b. Kelompok Kontrol}

Hasil pemeriksaan kemampuan $\mathrm{VO}_{2} \max$ pada saat pre test menunjukkan nilai ratarata kemampuan $\mathrm{VO}_{2} \max$ sebesar 34,9 dan standar deviasi sebesar 0,4722. Setelah pemberian minuman air mineral pada sampel kemampuan $\mathrm{VO}_{2}$ max pada saat post test dengan rata-rata sebesar 35,1 dan standar deviasi sebesar 0,4549.

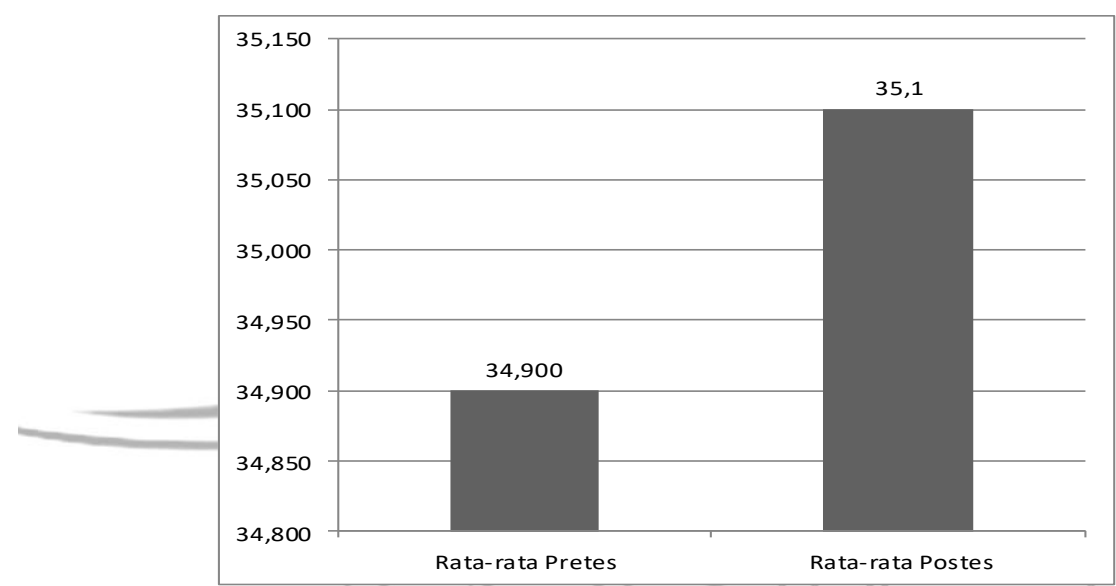

Gambar 2. Histogram Rata-Rata Kemampuan $V_{2}$ max Kelompok Kontrol

Uji Normalitas

Tabel 4.

Hasil Uji Normalitas

\begin{tabular}{cccccc}
\hline \multicolumn{2}{c}{ Kelompok } & $\begin{array}{c}\text { Hasil Sig. (Shaphiro } \\
\text { Wilk) }\end{array}$ & \multirow{2}{*}{$\begin{array}{c}\text { Kriteria } \\
\text { Normal }\end{array}$} & Keterangan \\
\hline \multirow{3}{*}{ Keksperimen } & Pre test & 0,497 & & \\
\cline { 2 - 3 } \cline { 2 - 2 } & Post test & 0,814 & & Normal \\
\cline { 2 - 3 } & Pre test & 0,457 & & Normal \\
\cline { 2 - 3 } & Post test & 0,163 & & Normal \\
\hline
\end{tabular}

Pada tabel 4, maka hasil uji normalitas dari kelompok eksperimen dan kelompok kontrol memiliki $\mathrm{p}>0,05$. Karena nilai probabilitas $(\mathrm{p})$ lebih besar dari 0,05 ( $\mathrm{p}>0,05)$ maka data kedua kelompok pemulihan berdistribusi "normal".

\section{Uji Homogenitas}

Tabel 5.

Hasil Uji Homogenitas

\begin{tabular}{cccc}
\hline Data & Hasil sig. & $\begin{array}{c}\text { Kriteria } \\
\text { Homogen }\end{array}$ & Kesimpulan \\
\hline Pre tes & 0,889 & $\mathrm{p}>0,05$ & Homogen \\
\hline Post tes & 0,411 & $\mathrm{p}>0,05$ & Homogen \\
\hline
\end{tabular}


Pada tabel 5 dapat dilihat Significancy Test Homogenity of Variances menunjukkan angka probabilitas $(\mathrm{p}>0,05)$, maka dapat ditarik kesimpulan bahwa kedua kelompok mempunyai varian yang sama atau "Homogen".

\section{Pengujian Hipotesis}

Tabel 6.

Perbedaan Nilai $\mathrm{VO}_{2} \max$ Pretes Dan Postes Kelompok Kontrol Dan Eksperimen

\begin{tabular}{|c|c|c|c|c|}
\hline \multicolumn{2}{|l|}{ Kelompok } & Rerata \pm SD & Nilai $p$ & Keterangan \\
\hline \multirow[t]{2}{*}{ Kontrol } & Pre test & $34,9 \pm 0,4722$ & \multirow{2}{*}{0,074} & Tidak \\
\hline & Post test & $35,1 \pm 0.4549$ & & Signifikan \\
\hline \multirow[t]{2}{*}{ Eksperimen } & Pre test & $35,7 \pm 0,6284$ & \multirow{2}{*}{0,074} & Tidak \\
\hline & Post test & $35,9 \pm 0,7981$ & & Signifikan \\
\hline
\end{tabular}

Dari tabel 6 adalah hasil uji-t berpasangan antara data pre-test dan post test kadar asam laktat pada kelompok eksperimen dan kelompok kontrol. Dapat dilihat pada kelompok eksperimen diperoleh nilai significancy $0,074(\mathrm{p}<0,05)$ yang berarti tidak ada perbedaan yang bermakna (tidak signifikan) dari nilai $\mathrm{VO}_{2} \mathrm{max}$ antara pre-test dan posttest.

Sedangkan dari kelompok kontrol dapat dilihat nilai significancy 0,074 ( $\mathrm{p}>0,05)$ yang berarti tidak ada perbedaan yang bermakna (tidak signifikan) dari nilai $\mathrm{VO}_{2}$ max antara pre-test dan post-test.

Tabel 7.

Perbedaan Nilai $\mathrm{VO}_{2} \max$ Post Tes Antara Minuman Beroksigen Dan Minuman Mineral

\begin{tabular}{lllcc}
\hline Kelompok & Rerata \pm SD & & Nilai p & Keterangan \\
\hline \multirow{2}{*}{ Post test } & Kontrol & $35,1 \pm 0,4549$ & \multirow{2}{*}{0.109} & \multirow{2}{*}{ Signifikan } \\
\cline { 2 - 3 } & Eksperimen & $35,9 \pm 0,7981$ & & \\
\hline
\end{tabular}

Uji t tidak berpasangan

Pada tabel 7 dapat dilihat bahwa dari hasil uji $\mathrm{t}$ independent (uji $\mathrm{t}$ tidak berpasangan) diperoleh rata-rata kenaikan nilai $\mathrm{VO}_{2} \max$ setelah pemberian minuman beroksigen dan minuman air mineral didapatkan bahwa $\mathrm{VO}_{2} \max$ kelompok kontrol diperoleh rata-rata sebesar 35,1 dengan standar deviasi 0,4549, sedangkan pada kelompok eksperimen diperoleh rata-rata sebesar 35,9 dengan standar deviasi 0,7981. Hasil uji statistik diperoleh nilai $\mathrm{p}=0,109$. Karena nilai $\mathrm{p}>0,05$ berarti dapat diambil kesimpulan bahwa tidak terdapat perbedaan yang bermakna (signifikan) antara kenaikan nilai $\mathrm{VO}_{2} \max$ Mahasiswa IKOR 2013 yang diberikan minuman beroksigen dengan minuman air mineral. Hal ini berarti tidak terdapat perbedaan yang signifikan antara 
pemberian minuman beroksigen dengan minuman air mineral terhadap kenaikan nilai $V_{2} \max$ Mahasiswa Ilmu Keolahragaan 2013 Universitas Negeri Medan.

Jika dilihat dari rata-rata nilai $V_{2} \max$ kelompok pemberian minuman beroksigen, diketahui bahwa sebelum dilakukan tes nilai $\mathrm{VO}_{2} \max$ diperoleh rata-rata 35,7 dan setelah diberikan minuman beroksigen dan dilakukan tes terdapat kenaikan nilai $\mathrm{VO}_{2}$ max menjadi 35,9 atau terjadi kenaikan nilai $\mathrm{VO}_{2}$ max sebesar 0,2. Sedangkan pada kelompok pemberian minuman air mineral diketahui bahwa sebelum dilakukan tes nilai $\mathrm{VO}_{2} \max$ diperoleh rata-rata 34,9 , setelah diberikan minuman air mineral dan dilakukan tes terdapat kenaikan nilai $\mathrm{VO}_{2} \max$ menjadi 35,1 atau terjadi kenaikan nilai $V O_{2} \max$ sebesar 0,2. Hasil tersebut membuktikan bahwa pemberian minuman beroksigen tidak berpengaruh untuk meningkatkan nilai $\mathrm{VO}_{2} \max$ Mahasiswa IKOR 2013.

\section{PEMBAHASAN PENELITIAN}

Uji t tidak berpasangan menyatakan tidak terdapat pengaruh signifikan dari "pemberian minuman beroksigen terhadap nilai $\mathrm{VO}_{2}$ max setelah melakukan lari bleep test pada Mahasiswa IKOR 2013 Fakultas Ilmu Keolahragan Universitas Negeri Medan yang dimana dari hasil analisis data tersebut diperoleh hasil sebesar 0,109>0,05. Dari hasil peneitian dan hasil analisis data dapat disimpulkan tidak terdapat pengaruh signifikan pemberian minuman beroksigen terhadap nilai $\mathrm{VO}_{2}$ max setelah melakukan bleep test pada Mahasiswa IKOR 2013 Fakultas Ilmu Keolahragan Universitas Negeri Medan.

Penelitian tentang pengaruh minuman beroksigen terhadap uji fungsi paru sejauh ini belum diketahui. Sedangkan pengaruh minuman beroksigen terhadap performa fisik itu pernah dilakukan. Pada penelitian ini dilakukan penelitian tentang pengaruh minuman beroksigen yang beredar dipasaran terhadap nilai $\mathrm{VO}_{2} \max$ Mahasiswa Ilmu Keolahragaan stambuk 2013 Universitas Negeri Medan.

Beberapa penelitian yang berhubungan dengan mengkonsumsi minuman beroksigen terhadap latihan fisik sudah pernah dipublikasikan. Jenkins A dkk melaporkan dalam suatu penelitian dengan kesimpulan mengkonsumsi minuman beroksigen akan memperbaiki saturasi oksigen dan menyatakan minuman beroksigen lebih baik pada atlit yang terlatih. Young R melaporkan dalam suatu penelitian terhadap 8 atlit sepeda mendapatkan semua atlit bersepeda lebih cepat, produksi asam laktat yang 
rendah, $\mathrm{VO}_{2}$ max yang lebih rendah dan frekuensi jantung lebih rendah pada kecepatan yang sama sebelum minum air beroksigen. Baker JD, Carey DG dan Beck BK melaporkan dalam suatu penelitian terhadap 8 orang atlit yang minum air beroksigen menyimpulkan terjadi peningkatan yang signifikan terhadap performa, kekuatan, daya tahan dan kecepatan. Tetapi pada penelitiannya Willmert $\mathrm{N}$ dkk menyimpulkan minuman beroksigen tidak memberikan pengaruh terhadap nilai $\mathrm{VO}_{2} \max$.

Robins M dan Glesson K melaporkan dalam suatu penelitian dangan kesimpulan pemberian oksigen pada latihan dapat meningkatkan daya tahan. Andreacci JL dkk melaporkan dalam suatu penelitian yang membandingkan konsumsi oksigen maksimal antara orang kulit hitam dan kulit putih(prepubertas dan pubertas) menyimpulkan tidak ada perbedaan di antara kedua kelompok. Dari kedua penelitian tersebut terlihat bahwa pemberian oksigen selama latihan fisik dapat meningkatkan daya tahan tubuh dan $\mathrm{VO}_{2}$ max tidak dipengaruhi oleh perbedaan warna kulit.

Pada penelitian ini tidak ada perbedaan dalam hal perubahan fungsi paru dan $\mathrm{VO}_{2}$ max antara kelompok yang minum minuman beroksigen dengan air minum mineral. Penelitian ini mungkin dapat menambah wawasan tentang minuman beroksigen. Dari penelitian ini bisa disimpulkan bahwa tidak ada perbedaan antara mengkonsumsi minuman beroksigen dengan air minum mineral sebelum latihan fisik terhadap nilai $\mathrm{VO}_{2} \max$ Mahaiswa Ilmu Keolahragaan stambuk 2013 Universitas Negeri Medan.

Pada hasil penelitian ini terdapat perbedaan tidak bermakna secara statistik antara nilai VO2Max pada kelompok air minum beroksigen dengan kelompok air mineral. Hal ini dikarenakan peningkatan kandungan oksigen dalam tubuh hanya terjadi saat kita meningkatkan performa tubuh dengan cara melakukan aktivitas fisik bukan dengan mengkonsumsi air minum yang ditambah kandungan oksigen. Selain itu solubilitas oksigen di dalam air sangat rendah dan tidak diketahui apakah kandungan oksigen di dalam air minum dapat diabsorbsi menuju saluran gastrointestinal. Karena intestinum tidak memiliki fungsi pertukaran gas seperti paru-paru dan oksigen yang diabsorbsi melalui intestinum dapat diabaikan pengaruhnya secara sistemik. Menurut penelitian secara analitik didapatkan bahwa kandungan oksigen yang ditambahkan dalam air minum hanya mengandung kurang dari oksigen per liter dari satu kali saat kita melakukan inspirasi. Faktor lain yang menyebabkan penelitian ini tidak signifikan 
adalah kurangnya keseriusan para sampel dalam melakukan tes, diperlukan pengawasan terhadap sampel agar sampel lebih serius melakukan tes dan melakukannya semaksimal mungkin. Dan menurut peneliti sampel juga dapat digantikan dangan atlet yang memiliki nilai VO2max yang tinggi dan takaran minumannya juga ditambah.

Nilai $\mathrm{VO}_{2} \mathrm{Max}$ sendiri berbeda pada tiap individu karena kondisi fisik seseorang mempengaruhi besarnya konsumsi oksigen maksimal. Sebagai contoh pada orangorang yang sedenter memiliki nilai $\mathrm{VO}_{2} \mathrm{Max}$ yang paling rendah, sedangkan pada endurance atlet memiliki nilai $\mathrm{VO}_{2} \mathrm{Max}$ yang tertinggi. Hal tersebut dapat diartikan bahwa model dan intensitas latihan seseorang mempengaruhi hasil nilai $\mathrm{VO}_{2} \mathrm{Max}$ ini. Perbedaan komposisi tubuh seseorang juga menyebabkan konsumsi oksigen yang berbeda. Tubuh yang memiliki kandungan lemak dengan presentase tinggi, mempunyai $\mathrm{VO}_{2} \mathrm{Max}$ yang lebih rendah. Otot yang kuat akan memiliki $\mathrm{VO}_{2} \mathrm{Max}$ lebih tinggi. Hereditas juga berpengaruh terhadap $\mathrm{VO}_{2} \mathrm{Max}$, seseorang mungkin saja mempunyai potensi yang lebih besar dari orang lain untuk mengkonsumsi oksigen yang lebih tinggi, dan mempunyai suplai pembuluh darah kapiler yang lebih baik terhadap otot-otot, mempunyai kapasitas paru-paru yang lebih besar, dapat mensuplai hemoglobin dan sel darah merah yang lebih banyak dan jantung yang lebih kuat.

\section{KESIMPULAN}

Berdasarkan hasil penelitian, pembahasan dan hasil analisis data tidak terdapat pengaruh signifikan pemberian minuman beroksigen setelah melakukan bleep test Mahasiswa Ilmu Keolahragaan Universitas Negeri Medan. Hal ini dibuktikan dengan pengujian hipotesis yang diperoleh dari Uji t tidak berpasang sebesar 0,109 > 0,05.

\section{Daftar Pustaka}

Astrand. P.O.; Rodahl. K. 1970. Text book of Work Physiology, Mc Graw. Hill Kogakusha, Ltd.; 388-389.

Bain, B.J. 2006. Haemoglobin opathy Diagnosis, 2nd Edition. Blackwell PublishingInc., Massachusetts.

Belitz, H.D. dan Grosch, W. 1999. Food Chemistry, 2nd Edition. Springer-Verlag, Berlin.

Billiar, T.R. dan Curran R.D. 1992. Hepatocyte and Kupffer Cell Interactions. CRC Press Inc., Florida.

Brewer, J., Ramsbottom, R., \& Williams, C. 1988. Multistage fitness test: Aprogressive shuttle-run test for the prediction of maximum oxygen uptake. Belconnen, ACT: Australian Coaching Council. 
Davies, A. dan Moores, C. 2003. The Respiratory System. Elsevier Science. Ltd. London.

Depkes RI. 2005. Petunjuk Teknis Pengukuran Kebugaran Jasmani, DirJen Bina Kesehatan Masyarakat, Departemen Kesehatan Jakarta.

Eagleson, M. 2008. Concise Encyclopedia Chemistry.Walter de Gruyter, Berlinand New York.

Five, B. 2001. The Detox Book, 2nd Edition. Piccadilly Books Ltd., Colorado.

Giriwidjoyo, YS. Santosa. 1992. Manusia dan Olahraga: Kesehatan, Kebugaran Jasmani dan Olahraga, Kerjasama ITB-FPOK IKIP Bandung. Penerbit ITB.Joesoef,

Gurskaya, N.V. dan Ivanov, K.P. 1961. Gaseous Equilibrium between Blood andthe Lumen of the Intestine. Bulletin of Experimental Biology and Medicine vol. 50 (3):910-912.

Guyton, A.C. dan Hall, J.E. 2006. Textbook of Medical Physiology, 10th Edition.W. B. Saunders Company, London.

Harris, D. 2007. Ensiklopedi Unsur-Unsur Kimia. Edisi Kedua. Penerbit Kawan Pustaka, Jakarta.

Johnson, L.R. dan Byrne, J.H. 2003. Essential Medical Physiology. Academic Press, California.

Lehninger, A. 1982. Dasar-Dasar Biokimia. Terjemahan: Maggy Thenâwijaya. Penerbit Erlangga, Jakarta.

Levitzky, M.G. 2003.Pulmonary Physiology, 6th Edition. McGraw-Hill Companies Inc., Indiana.

McIver, M.A., Redfields, A.C. dan Benedict, E.B. 1928. Gaseous Exchange between the Blood and the Lumen of the Stomach and Intestines.American Journal Physiology vol. 76: 92-111.

Mortimer, C.E.1975. Chemistry: A Conceptual Approach, 3rd Edition. D. Van Nostrand Co., New York.

Nestle, E., Wunderlich, A., dan Muessle-Kuegele, K. 2004. In vivo Observationof Oxygen Supersaturated Water in Human Mouth and Stomach. Magnetic Resonance Imaging vol. 22 (4): 551-556.

Oxtoby, D.W., Gillis, H.P., Nachtrieb N.H., dan Campio, A. 2007. Principles of Modern Chemistry. Thomson Brooks/Cole Publisher, California.

Parker, R. 2003. Introduction to Food Science. Delmar, Thomson Learnig, Inc.,New York.

Ramsbottom et al.1988. A progressive shuttle run test to estimate maximal oxygen uptake.British Journal of Sports Medicine 22: 141-5.

Rhoades, R.A. dan Bell, D.R. 2009. Medical Physiology. Lippincott Williams \&Wilkins, Maryland.

Roach, R.C., Wagner, P.D., dan Hackett, P.H. 2001. Hypoxia: From Genes to the Bed side. Plenum Publisher, New York.

Thomas, M. 2005. Understanding the Element of the Periodic Table Oxygen. The Rosen Publishing Group Inc., New York.

Weissman, I.L., Hood L.E., dan Wood, W.B. 1978. Essential Concepts in Immunology. The Benjamin Cummings Publishing Co. Inc., California.

Wong, N.H. dan Huang, B. 2004. Comparative Study of the Indoor Air Quality of Naturally Ventilated and Air-Conditioned Bedrooms of Residential Buildings in Singapore. Builing and Environment 39: 1115-1123. 